\title{
The Influence of Tourists on Stopover City: A Case Study of Burqin City Influenced by Kanas Scenic Area in Xinjiang Uygur Autonomous Region in China
}

\author{
Han Chun-xian \\ Yangzhou University, Yangzhou, China \\ Xinjiang University, Urumqi, China \\ Wu Di-shu \\ Xinjiang University, Urumqi, China
}

\begin{abstract}
Researches of tourism impact usually pay more attention to tourism destination but less attention to the stopover city of tourists. This paper researched the economic impact of tourism destination development on stopover city, Burqin, the case study city, which is a county center of less developed region in northwest of China and is a stopover city for tourists going to Kanas scenic area. We analyzed the impacts on industrial structure and urbanization of Burqin city on the bases of local statistical data through the correlation analysis approach. Then, we analyzed the difference of income and expenditure of residents whose job was relative to tourism compared to those residents whose job was not relative to tourism. At last, 10 variables were chosen from relative documents using the 5-point Likert scale to measure the residents' perception of the economic influence of tourists at Burqin according to Fishbein model. Research showed that industrial structure, urbanization, residents' income and expenditure of Burqin have improved, and urban economy has also improved.
\end{abstract}

Keywords: tourism development, stopover city, tourism economic impact, resident perception

\section{Introduction}

What would be influenced when large quantity of visitors arriving at a tourism destination was one of the key problems that tourism geographers paid attention to (Bao \& Chu, 1999; Hall \& Page, 2007)? Crouch and Ritchie (1999) showed that tourism development would have positive influences like improving expenditure, offering jobs, improving infrastructure, etc., but also negative influences like price increase, real estate speculation, environment damage, etc.. Influences of tourism industry to destination were divided into three dimensions by researchers: economic, environmental, and social (Ap, 1992; Brunt \& Courtney, 1999; Smith \& Krannich, 1998; Huang \& Wu, 2003; Li, 2006; Nunkoo \& Gursoy, 2012), or divided into five dimensions such as negative social impact, negative environmental impact, negative economic impact, positive social impact, and positive economic impact (Gursoy, Chi, \& Dyer, 2010; Lee, Kang, Long, \& Reisinger, 2010). Tourism

Han Chun-xian, Associate Professor, College of Tourism and Culinary Science, Tourism Department, Yangzhou University; Key Laboratory of Oasis Ecology, Xinjiang University. Email: chunxian-han@163.com.

Wu Di-shu, Master Graduate Student, Key Laboratory of Oasis Ecology, Xinjiang University. 
impact researches showed more interest in tourism destinations (Dyer, Aberdeen, \& Schuler, 2003; Ryan, 2002; Ap, 1990; Sheldon \& Var, 1984; Lankford, J. S. Y. Chen, \& W. Chen, 1994), but less interest in stopovers. This paper would analyze the influence of tourism destination on a stopover city Burqin according to statistical data and residents' perception, and it also measured the economic changes of Burqin, a stopover city under the influences of Kanas destination tourism development in the undeveloped region of northwest China.

\section{Case Study Area}

\section{Tourism Development of Kanas Scenic Area}

Kanas is a well-known and typical scenic area of Xinjiang which belongs to the Kanas Nature Reserve (KNR). KNR is located in northwest Xinjiang Uygur autonomous region in northwest China, at

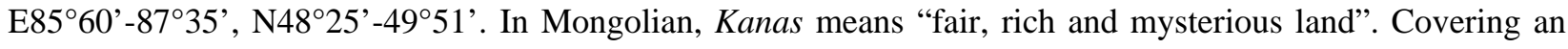
area of about 10,000 square kilometers, KNR is bordered by China, Kazakhstan, Russia, and Mongolia (Wang, Z. P. Yang, Chen, J. Yang, \& Li, 2010). Tourism development of Kanas began in 1993. It had received 18,500 tourists from 1985 to 1992, and since 1993, its tourist arrivals had been increasing continually. Tourists' increase rate was 5.40 during 1993-2000, and was 7.94 during 2001-2010. The number of tourist arrivals suddenly grew in 2006 because much money was used by Tourism Board of Xinjiang in tourism marketing during 2004-2005, then it decreased in 2008 because residents' movement between provinces was limited by Chinese government more or less during the Beijing Olympic Games in 2008, and continued to fall in 2009 because of the "violent crimes" on July 5, 2009 at Urumqi, which was the administrative center city of Xinjiang and the distribution center city of visitors in and out of Xinjiang. As a result, there were lower tourist arrivals in 2009 and 2010 than in 2006 and 2007 (see Figure 1). Tourist arrival went back to normal level under the national government support in 2011.

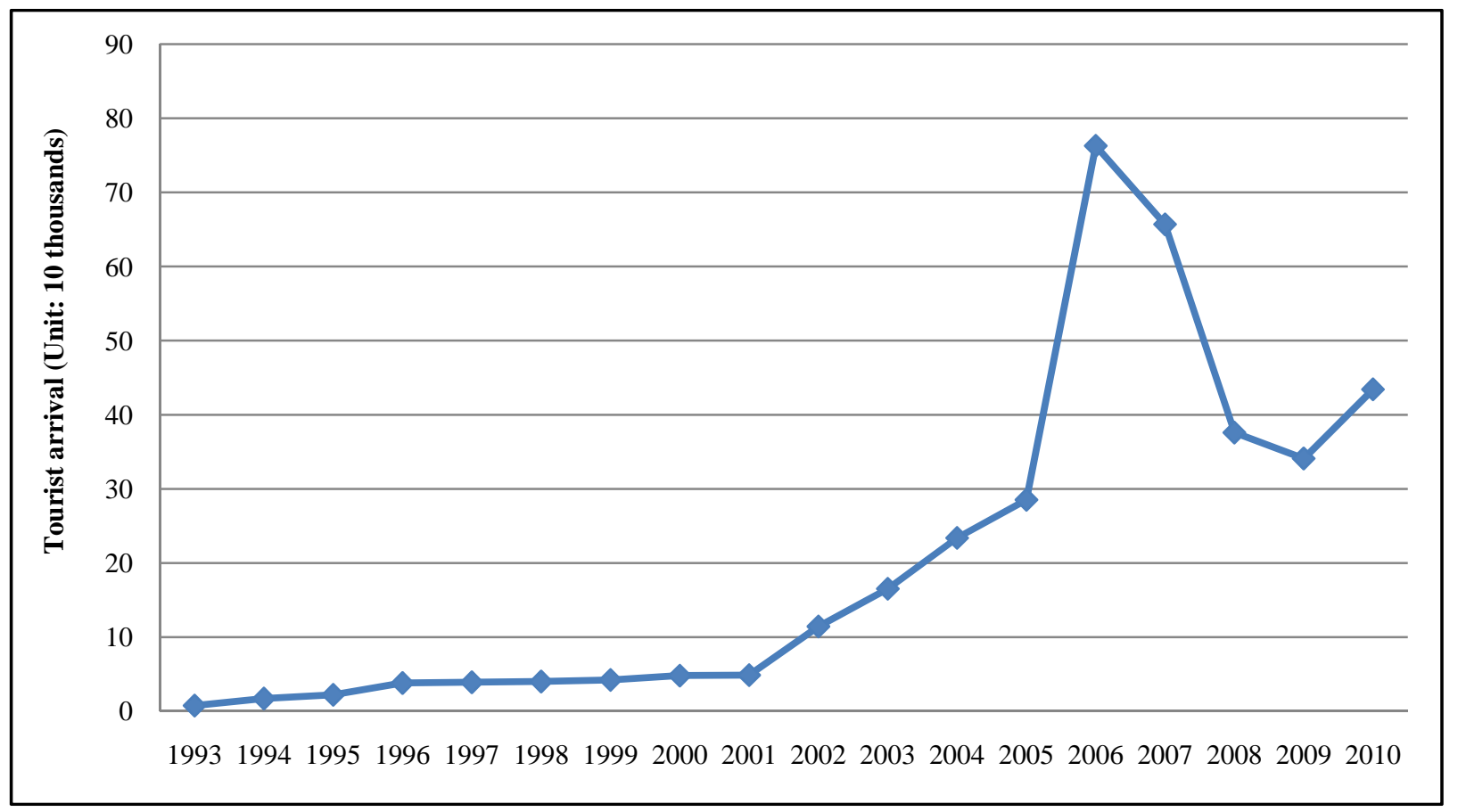

Figure 1. Tourism development of Kanas. 


\section{Burqin - Stopover City}

Burqin is the center city of Burqin county with 27,000 non-agricultural population in 2009. It is one of the six counties of Altay region in northwest Xinjiang, with the other five counties being Habahe, Fuyun, Fuhai, Qinghe, and Jimunai. Burqin city locates to 850 kilometers northwest of Urumqi which is the capital and hub city of Xinjiang Uygur autonomous region, 110 kilometers southwest of Altay city which is one of the nine regions of Xinjiang, and 198 kilometers south of Kanas scenic area, a stopover for overnight tourists from Urumqi to Kanas scenic area by car. City transportation, infrastructure, tourism service facilities, and environment had been improved by local government municipal construction investment (2,280,000 RMB invested by local government in 2006 and 13,000,000 RMB in 2009) with the stopover visitors increasing. As a result, unban tourism service function was enhanced rapidly, e.g., tourist hotel industry grew rapidly with 16 three-star hotels and four four-star hotels in 2009, while there was just one two-star hotel in 1992.

\section{Research Methodology}

The research includes two parts: the first part is concerned with tourism impact on the industrial structure and urbanization of Burqin with research data gathered from local government statistics using correlation analysis method. The second part was about tourism impact on urban economy, using research data gathered by distributing questionnaires to residents and conducting face-to-face interviews with the residents. Because tourists' activities concentrated mainly in urban Burqin, the interview was concentrated in urban area. Residents' interviews were selected randomly from different blocks door by door from September 30, 2009 to October 7, 2009. Altogether, there were 300 residents being interviewed and finally, we got 295 effective questionnaires.

The questionnaire includes three parts, the first part deals with demographic and social characteristics, the second part is about the difference in income and expenditure of residents in different seasons, and the third part is concerned with tourism impact on urban economy. Ten variables were chosen to analyze tourism impact on urban economy according to variables collected by Li, Han, and Yang (2010), which were employment opportunities, income, life level, price of supplies and service, price of local land and house, local infrastructure, personal tax, foreign investment, entertainment and leisure opportunities, and the gap between the rich and the poor.

Residents samples were divided into two sorts so that tourism impact could be analyzed comparably: one sort comprised residents whose jobs were relative to tourism industry and the other comprised residents whose jobs had nothing to do with tourism industry. Problems like whether their income and expenditure were different during tourist season and tourist off-season, what were the residents' perceptions of tourism impact, were analyzed respectively through approaches of comparative analysis and mathematical analysis. According to Fishbein attitude scale developed by Ap and Crompton (1998) in tourism study field, changes and assessment attitude to changes of residents' perception were separately measured in this research. The questionnaire was designed based on the 5-point Likert scale. Tourism changes were divided into five types for measurement, ranging from 5 = much change/improvement, 4 = some change/improvement, 3 = no change/improvement, 2 = some decrease/reduction, 1 = much decrease/reduction. Assessment attitudes to changes were also divided into five types, ranging from $5=$ very satisfied, $4=$ some satisfaction, $3=$ common/ordinary, $2=$ not very satisfied, 1 = not satisfied. Measurement results of changes and attitudes to changes perceived by residents were analyzed according to mean values divided by Tosun (2002): 1-2.4 = negative (no changes or no satisfaction); 2.5-3.4 = neutral (no clearly change or neutral attitude); and 3.5-5 = positive (changes or satisfaction). 


\section{Results and Analysis}

\section{Influence of Kanas Scenic Area Tourism Development on Industrial Structure and Urbanization of Burqin}

Tourism impact on Burqin county could be measured through comparison with the whole six counties' economic development level of Altay region. Their industrial structure of production proportion changed differently, the first industrial production proportion of Burqin county and the whole six counties of Altay had decreased during 1995-2009 (see Figures 2-3), the second industrial production proportion had increased in six counties but decreased in Burqin county, while the third industrial production proportion had decreased in the whole six counties and increased in Burqin. As a result, the industrial structure changed from the first industrial production primarily into the third industrial production primarily in Burqin with the second industrial production proportion fluctuating within 25\%-40\%, while industrial structure of the whole six counties of Altay region changed from the first industrial production primarily into the second industrial production primarily, with the third industrial production proportion fluctuating up and down $30 \%$.

Urbanization of the whole six counties of Altay increased 8\%, from 30\% in 1995 to 38\% in 2009 (see Figure 4). Correlation analysis between urbanization and three industrial production showed that Pearson positive correlation between urbanization of the whole six counties and their second industrial production was 0.93 ( $\alpha=0.01,2$-tailed) and that Pearson positive correlation between urbanization of Burqin and its third industrial production was 0.89 ( $\alpha=0.01$, 2-tailed) (see Table 1 ). That was to say, the second industry was the positive driving force of the whole counties of Altay region's economic growth and was the driving force of industrial structure change and urbanization, while the third industry was the positive driving force of Burqin economic growth, industrial structure change, and urbanization. Further correlation analysis showed that degree of correlation between the third industry of Burqin and tourist arrivals of Kanas scenic area was 0.79 ( $\alpha=0.01$, 2-tailed). All those proved that tourism development of Kanas scenic area improved the third industrial production growth and urbanization of Burqin.

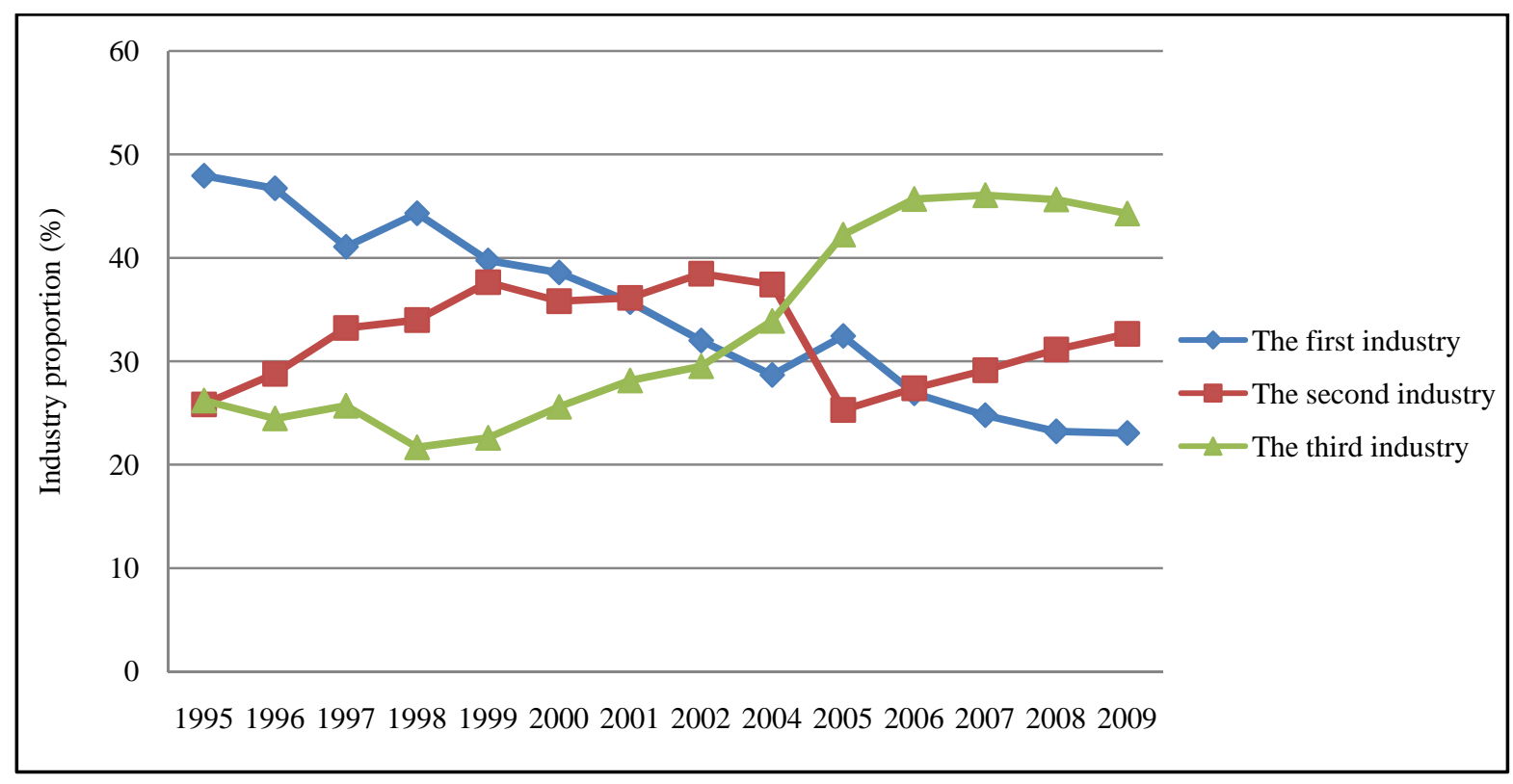

Figure 2. Three industries production proportion changes of Burqin county. 


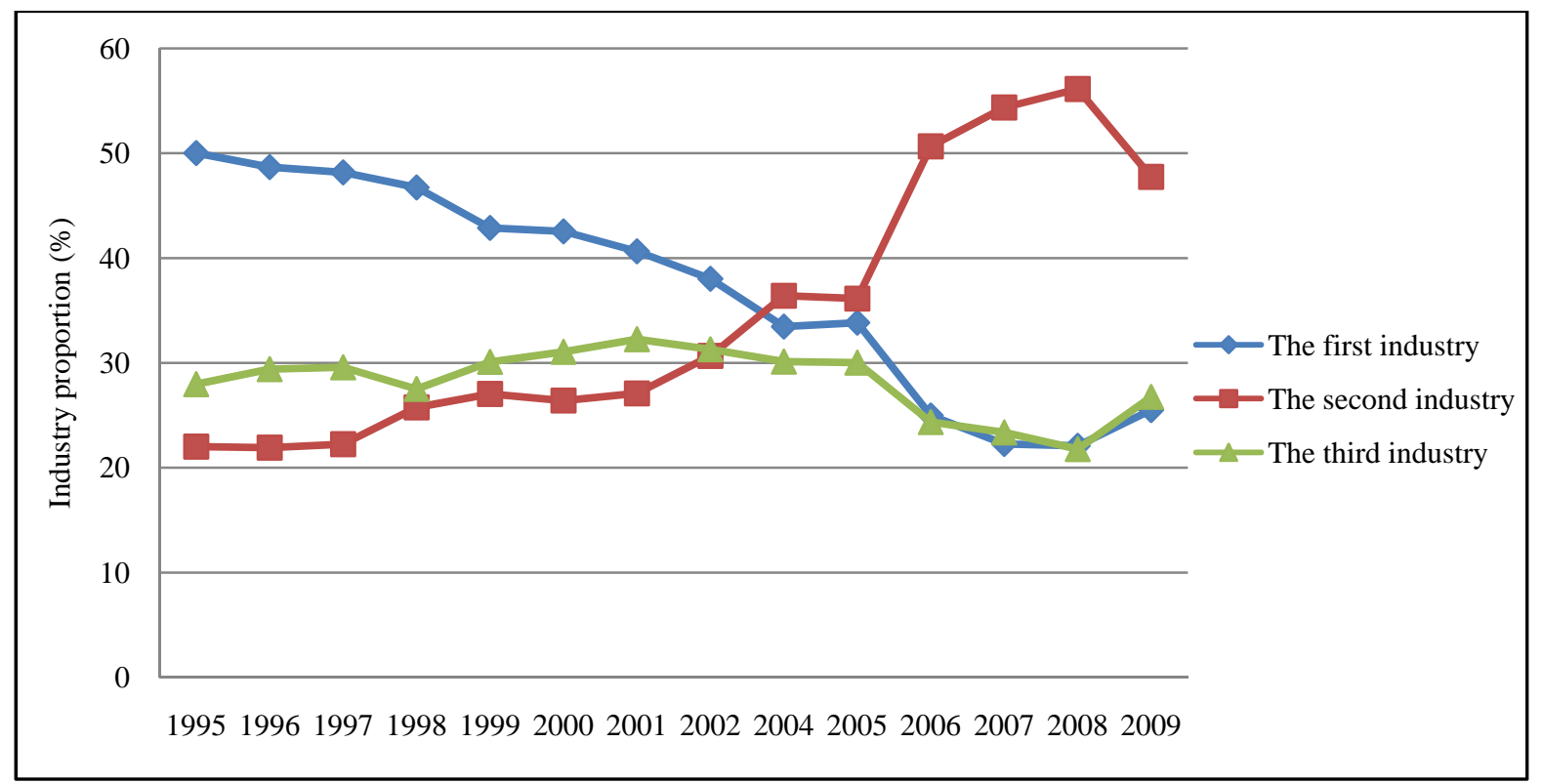

Figure 3. Three industries production proportion changes of the whole six counties of Altay region.

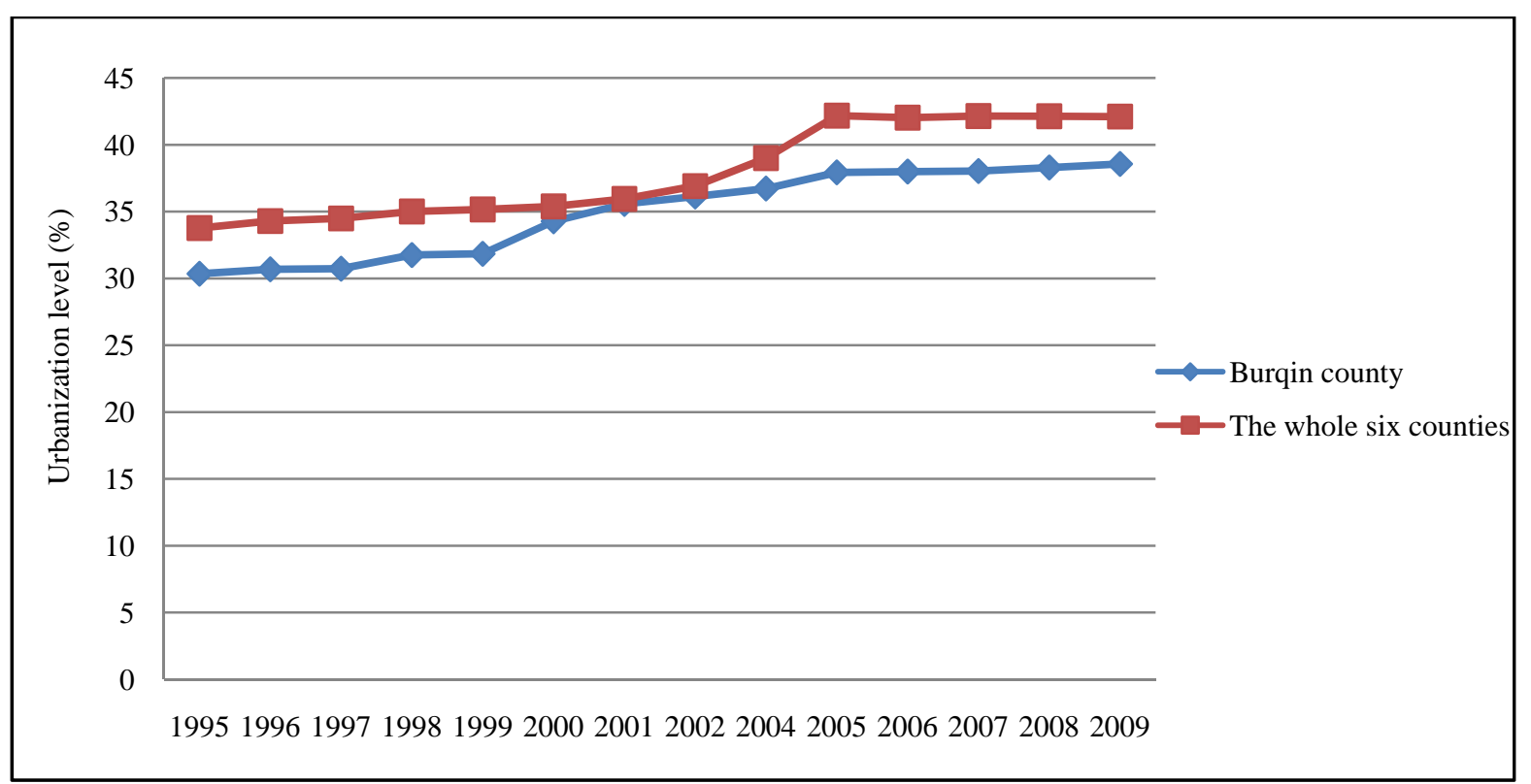

Figure 4. Urbanization level of Burqin county and the whole six counties of Altay region.

Table 1

Degree of Correlation Between Urbanization and Three Industries of Burqin and the Whole Six Counties of Altay Region During 1995-2009

\begin{tabular}{lll}
\hline Pearson correlation coefficient & The whole six counties of Altay region & Burqin county \\
\hline Between urbanization and the first industry proportion & $-0.96^{* *}$ & $-0.95^{* *}$ \\
Between urbanization and the second industry proportion & $0.93^{* *}$ & -0.07 \\
Between urbanization and the third industry proportion & $-0.62^{*}$ & $0.89^{* *}$ \\
\hline
\end{tabular}
Note. 2-tailed; ${ }^{* *}: \alpha=0.01,{ }^{*}: \alpha=0.05$. 
Changes of industrial structure and urbanization would also lead to changes in the economy and life of the city. What changes would be in Burqin? Would those changes be satisfied by residents? What would be produced in further analysis according to residents' perception of economic change and assessment resulting from tourists' activities and attitude to those changes?

Table 2

Demographic and Social Characteristics of Tourism Impact Survey Sample in Burqin City

\begin{tabular}{|c|c|c|c|c|c|c|c|}
\hline \multirow[t]{2}{*}{ Content } & \multirow[t]{2}{*}{ Type } & \multirow[t]{2}{*}{$N$} & \multirow{2}{*}{$\begin{array}{l}\text { Proportion } \\
\text { (\%) }\end{array}$} & \multicolumn{2}{|c|}{$\begin{array}{c}\text { Job related to tourism } \\
\text { industry }\end{array}$} & \multicolumn{2}{|c|}{$\begin{array}{c}\text { Job unrelated to tourism } \\
\text { industry }\end{array}$} \\
\hline & & & & $N$ & Proportion (\%) & $N$ & Proportion (\%) \\
\hline \multirow{2}{*}{ Gender } & Female & 144 & 48.81 & 31 & 43.66 & 113 & 50.45 \\
\hline & Male & 151 & 51.19 & 40 & 56.34 & 111 & 49.55 \\
\hline \multirow{4}{*}{ Age } & $15-24$ & 59 & 20.00 & 8 & 11.27 & 51 & 22.77 \\
\hline & $25-44$ & 138 & 46.78 & 44 & 61.97 & 94 & 41.96 \\
\hline & $45-64$ & 88 & 29.83 & 17 & 23.94 & 71 & 31.70 \\
\hline & $\geq 65$ & 10 & 3.39 & 2 & 2.82 & 8 & 3.57 \\
\hline \multirow{7}{*}{ Vocation } & Farmer & 6 & 2.03 & 0 & 0 & 6 & 2.68 \\
\hline & Worker & 76 & 25.76 & 12 & 16.90 & 64 & 28.57 \\
\hline & Student & 6 & 2.03 & 1 & 1.41 & 5 & 2.23 \\
\hline & Teacher & 37 & 12.55 & 2 & 2.82 & 35 & 15.63 \\
\hline & $\begin{array}{l}\text { Administrative institution } \\
\text { personnel }\end{array}$ & 62 & 21.02 & 3 & 4.22 & 59 & 26.34 \\
\hline & Retirees & 11 & 3.73 & 0 & 0 & 11 & 4.91 \\
\hline & Others & 97 & 32.88 & 53 & 74.65 & 44 & 19.64 \\
\hline \multirow{7}{*}{$\begin{array}{l}\text { Education } \\
\text { level }\end{array}$} & Unaccept the education & 3 & 1.02 & 1 & 1.41 & 2 & 0.89 \\
\hline & Primary & 6 & 2.03 & 1 & 1.41 & 5 & 2.23 \\
\hline & Secondary school & 53 & 17.97 & 17 & 23.94 & 36 & 16.07 \\
\hline & High school & 45 & 15.25 & 13 & 18.31 & 32 & 14.29 \\
\hline & Technical secondary school & 27 & 9.15 & 11 & 15.49 & 16 & 7.14 \\
\hline & Junior college degree & 103 & 34.92 & 25 & 35.21 & 78 & 34.82 \\
\hline & Bachelor degree and above & 58 & 19.66 & 3 & 4.23 & 55 & 24.56 \\
\hline
\end{tabular}

\section{Tourism Impact on City Economy}

Basic data. Altogether, there were 300 residents chosen to answer the questionnaires, and finally, we got 295 effective questionnaires, because the investigation was completed face to face. Of the total 295 residents investigated, 71 (24.1\%) residents' jobs are related to tourism industry, while the other 224 (75.9\%) residents' jobs are not. We consider that a resident's job is related to tourism industry if he/she or his/her family members worked in tourism industry; we consider that a resident's job is not related to tourism industry if he/she or his/her family members worked in other industries except tourism industry, and his/her family income came from other industries, too. The demographic characteristics of the sample were reasonable (see Table 2 above):

(1) Gender: males whose jobs were related to tourism industry accounted for $56.34 \%$, which was slightly higher than males whose jobs were not related to tourism industry (accounting for 49.55\%);

(2) Age: residents whose jobs were related to tourism industry were mainly between 25 and 44 years old, accounting for $61.97 \%$, and residents whose jobs were not related to tourism industry were mainly between 25 and 64 years old, accounting for $73.66 \%$; 
(3) Vocation: seventy one residents whose jobs were related to tourism industry were mainly operators and employees of tourism industry, among them, 53 residents were engaged in tourism industrial jobs, including operators and employees of hotels, lodges, restaurants, jade stores, etc., while the other 18 residents' family income came mainly from tourism industry, including 12 workers, two teachers, one student, and three administrative institution personnel. Residents whose jobs were not related to tourism industry were mainly employees of state-owned enterprises (64 enterprise workers) and administrative institutions (including 35 teachers, 11 retired persons, and 59 administrative institution personnel), which accounted for $75.45 \%$, followed by 44 residents with other vocations (including self-employed, doctors, soldiers, and drivers), six farmers, and five students, accounting for $19.64 \%, 2.68 \%$, and $2.23 \%$ respectively;

(4) Education level: residents in the sample mainly had junior college degree, but the education background of those whose jobs were related to tourism industry was slightly lower than those whose jobs were not related to tourism industry.

Influence of residents' income of Burqin. The influences of residents' income of Burqin dealt with in this paper include influences on annual and monthly income.

Influence on annual income. The annual income of both sorts of residents was 10,000-40,000 RMB (see Table 3). Income distribution of residents whose jobs were not related to tourism industry was fit for normal distribution. The majority of residents have an income of 10,000-20,000 RMB (29.46\%), 20,000-30,000 RMB (29.46\%), and 30,000-40,000 RMB (23.66\%), followed by residents having an income of above 50,000 RMB (6.70\%) and below 5,000 (2.23\%). Income distribution of residents whose jobs were related to tourism industry was unfit for normal distribution. The majority of residents have an income of 10,000-20,000 RMB (42.25\%), followed respectively by over 50,000 RMB (19.72\%), 20,000-30,000 RMB (14.08\%), and 30,000-40,000 RMB (12.68\%). Among them, there were five residents whose income was over 100,000 RMB, including three owners of tourism hotels and lodges with an annual income above 1,000,000, about 800,000, and 200,000 RMB, an owner of a tourism Jada shop with an annual income of over 200,000 RMB, and an owner of a tourism supermarket with an annual income about 100,000 RMB.

Table 3

Residents' Personal Annual Income Distribution of Burqin

\begin{tabular}{|c|c|c|c|c|}
\hline \multirow{2}{*}{$\begin{array}{l}\text { Personal annual } \\
\text { income (RMB) }\end{array}$} & \multicolumn{2}{|c|}{ Job related to tourism industry } & \multicolumn{2}{|c|}{ Job unrelated to tourism industry } \\
\hline & $\bar{N}$ & Proportion (\%) & $N$ & Proportion (\%) \\
\hline$>50,000$ & 14 & 19.72 & 15 & 6.70 \\
\hline $40,000-50,000$ & 4 & 5.63 & 10 & 4.46 \\
\hline $30,000-40,000$ & 9 & 12.68 & 53 & 23.66 \\
\hline $20,000-30,000$ & 10 & 14.08 & 66 & 29.46 \\
\hline $10,000-20,000$ & 30 & 42.25 & 66 & 29.46 \\
\hline $5,000-10,000$ & 2 & 2.82 & 7 & 3.13 \\
\hline$<5,000$ & 2 & 2.82 & 5 & 2.23 \\
\hline Other & & & 2 & 0.89 \\
\hline
\end{tabular}

Compared with the personal annual income of residents whose jobs were not related to tourism, the majority of residents (42.25\%) whose jobs were related to tourism had an annual income of 10,000-20,000 RMB (see Table 3), which was much more than the former, and $19.72 \%$ of them had an annual income of more than 50,000 RMB, which was higher than residents whose jobs were not related to tourism, and a few of them were the highest earners in local city. All the above showed that tourism development of the Kanas scenic area had contributed to Burqin economy by not only improving personal income but also widening personal income gap. 
Influence on monthly income. The tourist season of Kanas scenic area is from June to October, while the rest is off-season. Residents' average monthly income between tourist off-season and tourist season during the years of 2007-2009 showed that (see Figure 5):

(1) The average monthly income of residents whose jobs were tourism-related was 5,944.13 RMB in tourist seasons, which was 3.13 times as much as that of in tourist off-seasons which was 1,896.24 RMB, and their average monthly income had decreased gradually both in tourist season and tourist off-season from 2007 to 2009;

(2) The average monthly income of residents whose jobs were not related to tourism was almost the same between months: it was 1,432.53 RMB in tourist season and 1,417.80 RMB in tourist off-season. Their monthly income had slightly increased during 2007-2009, from 1,155.85 RMB in 2007, 1,511.07 RMB in 2008, to 1,621.07 RMB in 2009 during tourist season, and was 1,155.85, 1,486.07, and 1,611.47 RMB respectively in tourist off-season.

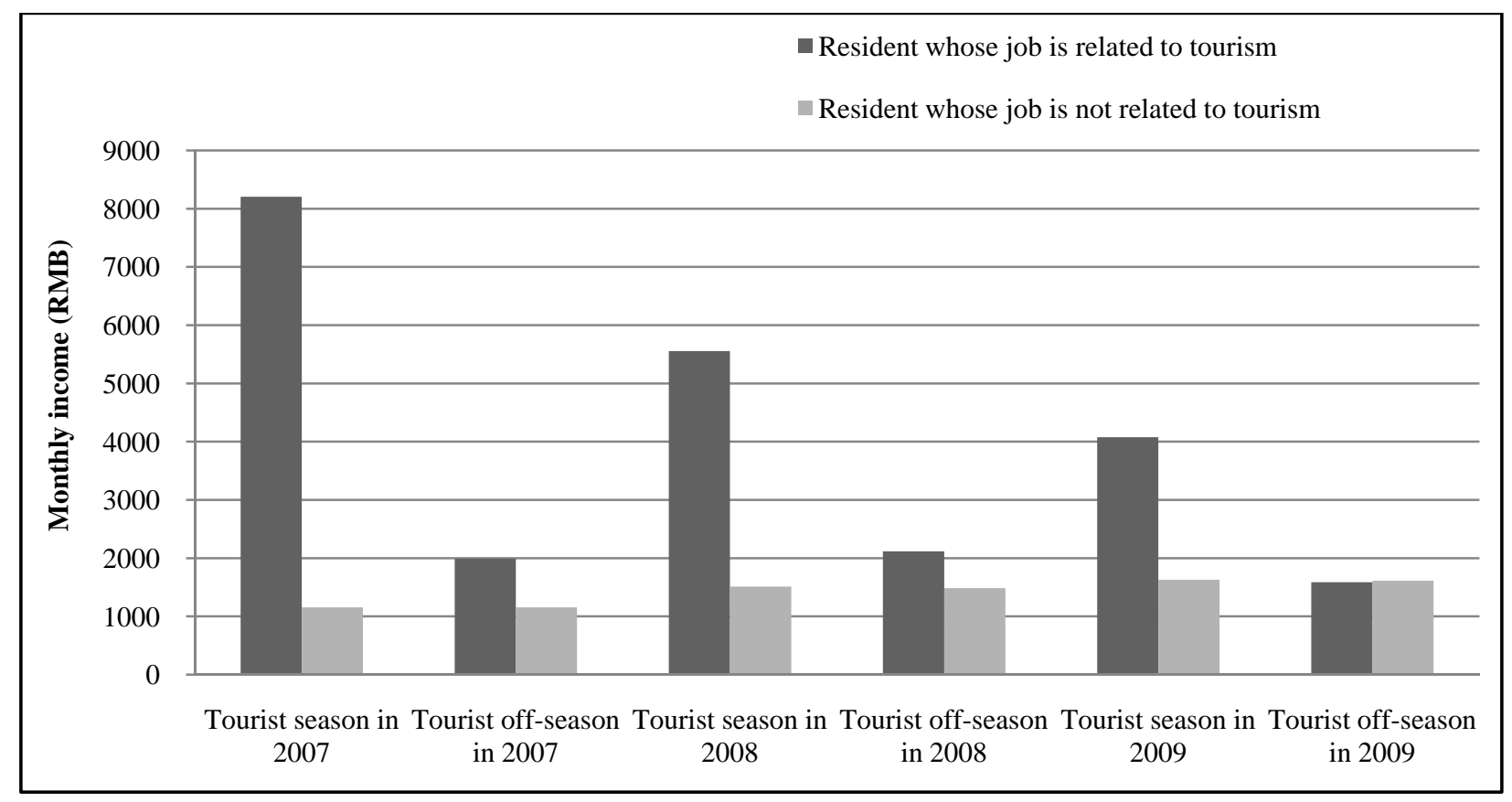

Figure 5. Average monthly income level of residents in Burqin.

The average monthly income of residents whose jobs were related to tourism had decreased because tourism industry was impacted by various events, such as the Beijing Olympic Games in 2008. During the Games time, domestic tourists flow was limited partly by the government so as to make sure that the event could be hosted in a safe social environment. As a result, tourist arrivals of the Kanas scenic area were low because the game time was just in the tourist season of Kanas scenic area. In addition, Xinjiang "Violent Crimes on July 5" happened in July 2009 when the tourist season of Kanas scenic area began, which impacted tourism industry of Xinjiang seriously, fewer tourists outside of Xinjiang had visited Kanas scenic area while the residents of Xinjiang were encouraged to visit inside Xinjiang in 2008 and 2009. It gave rise to the decrease of the monthly income of residents working in tourism industry from 2007 to 2009, and their income gap had also decreased in both tourist season and tourist off-season. 
Influence on household expenditure. The average monthly expenditure of residents whose jobs were related to tourism industry was 1,669.72 RMB in tourist season, 1,952.03 RMB in tourist off-season during 2007-2009, which was higher than residents whose jobs were not related to tourism, which was 992.01 RMB in tourist season and 999.33 RMB in tourist off-season at the same time. During the interview, residents whose jobs were related to tourism industry explained that they consumed mainly in tourist off-season because they were busy in tourist season and they hardly had time to consume in this season. The average monthly expenditure of residents whose jobs were related to tourism had decreased gradually, from 1,811.97 RMB in 2007, 1,625.35 RMB in 2008, to 1,571.83 RMB in 2009 in tourist season, and from 1,989.44 RMB in 2007, 1,935.21 RMB in 2008, to 1,928.45 RMB in 2009 in tourist off-season of the same year, while the average monthly expenditure of residents whose jobs were not related to tourism increased gradually from 844.2 RMB in 2007, 1,014.02 RMB in 2008, to 1,117.81 RMB in 2009 in tourist season and from 841.07 RMB in 2007, 1,026.29 RMB in 2008, to 1,130.63 RMB in 2009 in tourist off-season (see Figure 6). All those expenditure changes were just the same as their income change trends. They were:

(1) The expenditure of residents whose jobs were related to tourism was 1.8 times as much as that of the residents whose jobs were not related to tourism;

(2) The average monthly expenditure of residents whose jobs were related to tourism was influenced by tourist season, while the other sort of residents' expenditure was not influenced by tourist season;

(3) The average monthly expenditure of residents whose jobs were related to tourism decreased gradually as their income decreased, while the expenditure of the other sort of residents increased gradually as their income increased. It showed that residents' expenditure level of jobs relating to tourism was impacted by tourism industry obviously.

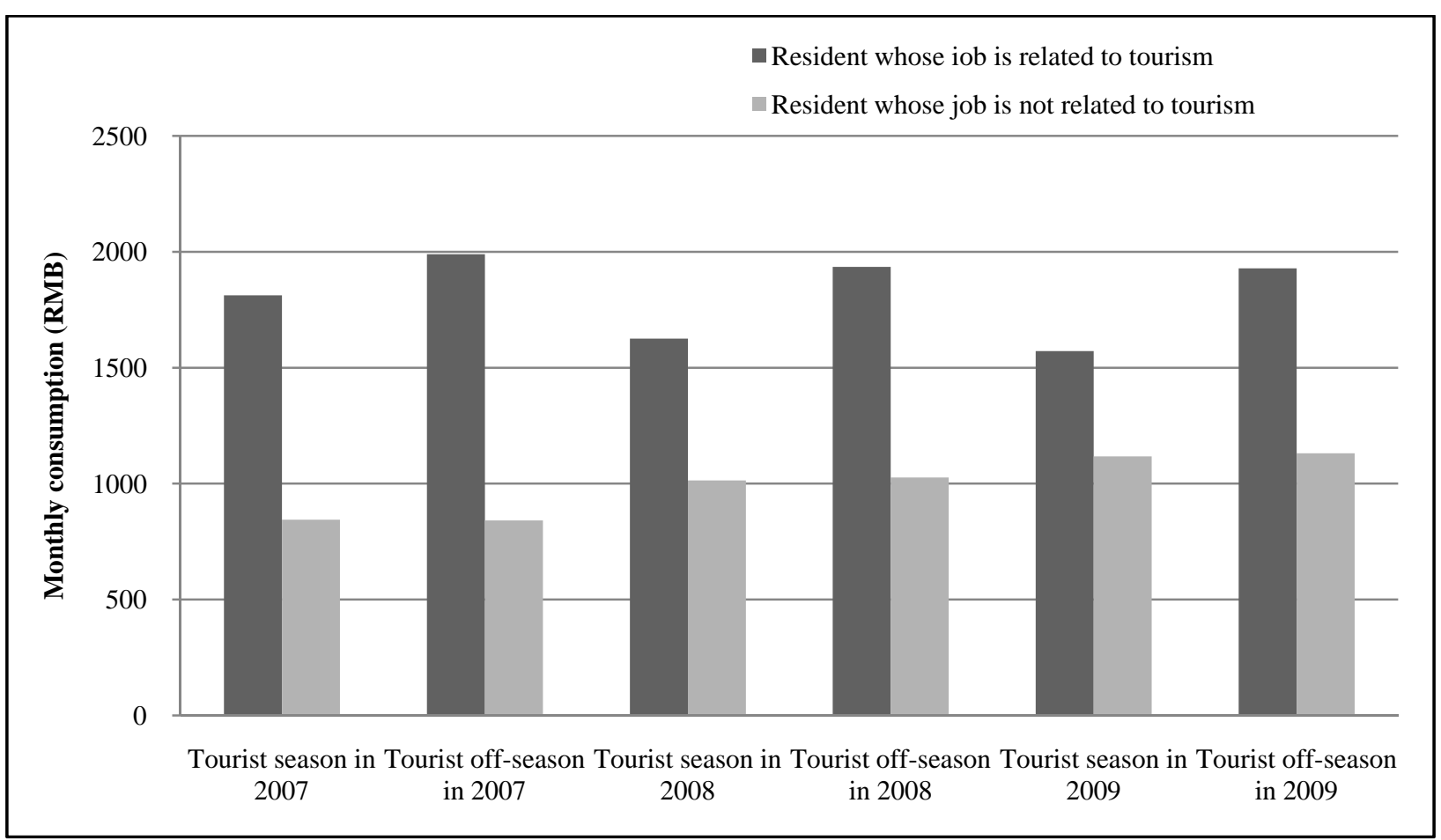

Figure 6. Average monthly expenditure of residents whose jobs were tourism-related and whose jobs were not related to tourism. 
Impact on urban economy from the perspective of residents. The mean values of changes perceived by residents in Burqin of 10 variables about urban economic situation were showed in Table 4. It showed that the majority of residents thought that tourism development of Kanas scenic area has some impact on Burqin urban economy except entertainment and their leisure opportunities:

(1) The most positive impact on Burqin urban economy was the increase of employment opportunities, local infrastructure, income, and living standards. The two sorts of residents investigated are satisfied with them;

(2) The most negative influence was price increase. Residents were unsatisfied because they perceived that price had been stable before Kanas scenic area was developed, and they cannot bear such a high price now;

(3) The two sorts of residents perceived that items of foreign investment and the gap between the rich and the poor had changed obviously, but showed different attitudes. The residents whose jobs were not related to tourism were satisfied with foreign investment and were neutral to gap between the rich and the poor. The other sort resident showed lower assessment score to them, they were neutral to foreign investment, and unsatisfied with gap between the rich and the poor, because they paid more attention to foreign investment which did not reach their expectations, and because they were next to the rich and the poor, and may be the poor themselves;

(4) The two sorts of residents perceived different changes happened to personal tax but showed the same neutral assessment. Residents whose jobs were not related to tourism perceived that their personal tax increased much more, while the other resident did not perceive that it had changed obviously.

Table 4

Mean Values of Tourism Economic Impact Perceived by Residents

\begin{tabular}{|c|c|c|c|c|}
\hline \multirow[t]{2}{*}{ Item } & \multicolumn{2}{|c|}{$\begin{array}{l}\text { Residents whose jobs are related to } \\
\text { tourism }\end{array}$} & \multicolumn{2}{|c|}{$\begin{array}{c}\text { Residents whose jobs are not related to } \\
\text { tourism }\end{array}$} \\
\hline & Change & Attitude & Change & Attitude \\
\hline Employment opportunities & 4.24 & 4.21 & 4.30 & 4.11 \\
\hline Income & 3.72 & 3.89 & 3.61 & 3.60 \\
\hline Living standards & 3.93 & 3.61 & 3.69 & 3.50 \\
\hline Price of supplies and service & 4.68 & 1.89 & 4.65 & 1.80 \\
\hline Price of local land and house & 4.69 & 1.70 & 4.65 & 1.78 \\
\hline Local infrastructure & 4.38 & 3.90 & 4.34 & 3.93 \\
\hline Personal tax & 3.63 & 2.70 & 3.32 & 2.89 \\
\hline Foreign investment & 4.20 & 3.18 & 4.23 & 3.60 \\
\hline Entertainment and leisure opportunities & 3.39 & 3.31 & 3.47 & 3.37 \\
\hline Gap between the rich and the poor & 4.27 & 2.41 & 4.07 & 2.73 \\
\hline
\end{tabular}

\section{Summary and Conclusions}

Crouch and Ritchie (1999) presented that tourism development would have both positive and negative influences on tourism destination. The positive influences include improving expenditure, offering jobs, improving infrastructure, etc., and negative influences contain price increase, real estate speculation, environment damage, etc.. This paper showed that the same economic influences also happened to stopover city in the underdeveloped region of China, Burqin, the stopover city, which was influenced by tourism destination development of Kanas scenic area, not only its industrial structure and urbanization but urban economy were influenced. Influences of stopover Burqin city were: 
(1) It promoted industrial structure transformation of Burqin, which turned from the first industry dominantly into the third industry dominantly, and promoted urbanization;

(2) Residents had got economic benefit from offering service for tourist activity in stopover city. The majority of residents whose jobs were related to tourism got a lower annual income, quite a proportion of this sort of resident had higher income, which made larger income difference than residents whose jobs were not related to tourism. The former had higher difference seasonal income, higher difference income level and more fluctuant income affected by events than the latter did. As a result, it showed that tourism development made residents whose jobs were tourism-related have a seasonal fluctuation income and uncertain income influenced by outside events and a more wide gap between the rich and the poor;

(3) Residents whose jobs were related to tourism had a higher expenditure level than whose jobs were not tourism-related, and their expenditure level changes were in line with the changes of the tourism industry of destination;

(4) From the perspective of residents, researches showed that residents perceived that the Kanas scenic area had an impact on Burqin city economy, too. The most positive influences on Burqin urban economy include the increase of employment opportunities, improvement of local infrastructure, increasing income, and better living standards, and all residents were satisfied with these changes. The most negative influences were price increase and the increasing gap between the rich and the poor, and residents showed dissatisfaction with these changes except residents whose jobs were not related to tourism as they were neutral to the increasing gap between the rich and the poor.

Therefore, destination tourism development improved economic development of stopover city effectively in undeveloped region in China, which was accompanied by problems of local price increase and increasing gap between the rich and the poor.

\section{References}

Ap, J. (1990). Residents' perceptions research on the social impacts of tourism. Annals of Tourism Research, 17(4), 610-616.

Ap, J. (1992). Residents’ perceptions on tourism impacts. Annals of Tourism Research, 19(4), 665-690.

Ap, J., \& Crompton, J. L. (1998). Developing and testing a tourism impact scale. Journal of Travel Research, 37(2), 120-130.

Bao, J. G., \& Chu, Y. F. (1999). Tourism geography (2nd ed.). Beijing: Higher Education Press.

Brunt, P., \& Courtney, P. (1999). Host perceptions of sociocultural impacts. Annals of Tourism Research, 26(3), 493-515.

Crouch, G. I., \& Ritchie, J. R. B. (1999). Tourism, competitiveness, and societal prosperity. Journal of Business Research, 44(3), 137-152.

Dyer, P., Aberdeen, L., \& Schuler, S. (2003). Tourism impacts on an Australian indigenous community: A Djabugay case study. Tourism Management, 24(1), 83-95.

Gursoy, D., Chi, C. G., \& Dyer, P. (2010). Locals' attitudes toward mass and alternative tourism: The case of sunshine coast, Australia. Journal of Travel Research, 49(3), 381-394.

Hall, C. M., \& Page, S. J. (2007). The geography of tourism and recreation: Environment, place and space (3rd ed.). Beijing: Tourism Education Press.

Huang, J., \& Wu, Z. (2003). A study of attitude by local residents of tourist destinations towards tourism impact. Tourism Tribune, $18,84-89$.

Lankford, S. V., Chen, J. S. Y., \& Chen, W. (1994). Tourism's impacts in the Penghu national scenic area, Taiwan. Tourism Management, 15(3), 222-227.

Lee, C. K., Kang, S. K., Long, P., \& Reisinger, Y. (2010). Residents’ perceptions of casino impacts: A comparative study. Tourism Management, 31(2), 189-201.

Li, D., Han, C., \& Yang, L. (2010). A review and comparison between the local residents perceptions of tourism influences in China and foreign countries. Human Geography, 25, 142-147. 
Li, Z. F. (2006). On the perception and attitude of mountainous residents in national minorites towards tourism impacts — $\mathrm{A}$ case study of Chaibuxi National Forest Park. Tourism Tribune, 21, 21-25.

Nunkoo, R., \& Gursoy, D. (2012). Residents’ support for tourism: An identity perspective. Annals of Tourism Research, 39(1), 243-268.

Ryan, C. (2002). Equity, management, power sharing and sustainability-Issues of the 'new tourism'. Tourism Management, 23(1), 17-26.

Sheldon, P. J., \& Var, T. (1984). Resident attitudes to tourism in North Wales. Tourism Management, 5(1), 40-47.

Smith, M. D., \& Krannich, R. S. (1998). Tourism dependence and resident attitudes. Annals of Tourism Research, 25(4), 783-802.

Tosun, C. (2002). Host perceptions of impacts: A comparative tourism study. Annals of Tourism Research, 29(1), 231-253.

Wang, H., Yang, Z. P., Chen, L., Yang, J., \& Li, R. (2010). Minority community participation in tourism: A case of Kanas Tuva villages in Xinjiang, China. Tourism Management, 31(6), 759-764. 